\title{
Biological treatment of leachate from stabilization of biodegradable municipal solid waste in a sequencing batch biofilm reactor
}

\author{
K. Bernat ${ }^{1} \cdot$ M. Zaborowska ${ }^{1} \cdot$ M. Zielińska ${ }^{1} \cdot$ I. Wojnowska-Baryła ${ }^{1} \cdot$ W. Ignalewski ${ }^{1}$
}

Received: 21 February 2020 / Revised: 24 June 2020 / Accepted: 1 September 2020 / Published online: 12 September 2020

(c) The Author(s) 2020

\begin{abstract}
The aim of this study was to determine the effectiveness of pollutant removal in sequencing batch biofilm reactors (with floating or submerged carriers) when treating nitrogen- and organic-rich real leachate generated during aerobic stabilization of the biodegradable municipal solid waste. A control reactor contained suspended activated sludge. The share of leachate in synthetic wastewater was $10 \%$, which resulted in ratios of chemical oxygen demand and biochemical oxygen demand to total Kjeldahl nitrogen in the influent of ca. 11 and ca. 8.5, respectively. Regardless of whether the reactors contained carriers or not, the effectiveness of nitrification (84.2-84.3\%) and of the removal of chemical oxygen demand (86.5-87.0\%), biochemical oxygen demand (95.5-98.0\%) and ammonium (88.9-89.3\%) did not differ. However, the presence of carriers and their type determined in which phase of the cycle denitrification occurred. In the control reactor, denitrification took place during mixing phase with the effectiveness of ca. $43.2 \%$ (57.7\% of the total nitrogen removal). During aeration, the oxygen content increased rapidly, thus reduced the possibility of simultaneous denitrification. In reactors with carriers, in the aeration phase, not only nitrification but also denitrification occurred. The increase in oxygen content in wastewater was slower, which could have caused dissolved oxygen gradients and anoxic zones in deeper layers of the biofilm and flocks. In the reactor with floating carriers, the effectiveness of denitrification and total nitrogen removal increased 1.23- and 1.10-times, respectively, as compared to the control reactor. The highest efficiencies (67.7\% and $73.0 \%$, respectively) were observed in the reactor with submerged carriers.
\end{abstract}

Keywords Activated sludge $\cdot$ Rate constant of oxygen consumption $\cdot$ Reactor with carriers $\cdot$ Nitrification $\cdot$ Simultaneous denitrification $\cdot$ Nitrogen removal

\section{Introduction}

Organic waste, for example, sewage sludge, organic municipal solid waste or green waste, must be stabilized. For this purpose, aerobic stabilization or composting is widely used solution (Roy et al. 2018). Both these processes proceed in the same way. However, in the case of, e.g., sewage sludge, selectively collected municipal organic waste or green waste, the process and its product are called composting and compost, respectively. This compost can be used as a fertilizer.

Editorial responsibility: M. Borghei.

M. Zaborowska

magdalena.zaborowska@uwm.edu.pl

1 Department of Environmental Biotechnology, University of Warmia and Mazury in Olsztyn, Sloneczna 45G, 10-709 Olsztyn, Poland
In the case of the organic fraction of municipal solid waste (OFMSW) that is mechanically separated from mixed municipal waste, the process and its product are called stabilization and stabilizate, respectively, and the stabilizate does not qualify as compost and must be landfilled.

During both aerobic stabilization and composting of organic waste, leachate is generated. The amount and composition of the leachate depend on various factors, including the type and composition of stabilized/composting waste, the technology used, as well as climatic conditions and seasonal variability of waste composition (Krogmann and Woyczechowski 2000; García-López et al. 2014). The color of the leachate after aerobic stabilization/composting is yellow to dark brown because it contains organic substances, e.g., humic substances.

The leachate contains various hazardous substances that can have potential adverse effects on the environment, and that therefore needs to be sufficiently treated prior to 
disposal (Chatterjee et al. 2013). The main contaminants are nitrogen and organic substances; moreover, leachate may contain sulfates, chlorides, heavy metals (He et al. 2015), pesticides, phthalates or polychlorinated biphenyls (Fromme et al. 2002) and polycyclic aromatic hydrocarbons (PAHs) (Hashemi et al. 2016). Leachate from aerobic stabilization/composting has a composition that is similar to that of leachate from young landfills (Siciliano et al. 2019). Such leachate is characterized by high concentrations of organic compounds expressed as chemical (COD) and biochemical (BOD) oxygen demand and is highly susceptible to biodegradation (Hashemi et al. 2015). Furthermore, leachate contains high concentrations of volatile fatty acids, which can cause slightly acidic pH (Mokhtarani et al. 2012). This leachate cannot be discharged to the receiver without appropriate treatment, but must be utilized, for example, in aerobic or anaerobic biological processes.

During anaerobic treatment, biogas is produced as an added value product. However, anaerobic digestion of only leachate from aerobic stabilization or composting may encounter some problems. This results from the fact that the $\mathrm{COD} / \mathrm{N}$ ratio in the leachate is not appropriate for the metabolism of anaerobic microorganisms, and for this reason, leachate should be supplemented with a co-substrate rich in organic substances. Moreover, despite the high effectiveness of organics removal under anaerobic conditions, COD concentrations in the digester effluent are high, reaching even 1000-4000 mg/L (Amin and Moazzam 2014). During the anaerobic process, nitrogen compounds are not removed, and the concentrations of ammonium and total nitrogen in the leachate after treatment are sometimes extremely high, up to hundreds of milligrams per liter (Çakmakci and Özyaka 2013) or even several thousand milligrams per liter (García-López et al. 2014). Therefore, after anaerobic treatment, the aerobic treatment should be applied to fulfill the demands of Polish law concerning pollutant concentrations in treated wastewater.

The activated sludge method is one of the most commonly used for wastewater treatment. Because the concentrations of organic and nitrogen compounds in the leachate from aerobic stabilization or composting are high, it is difficult to remove them in the side stream of treatment. In wastewater management systems, difficult-to-treat wastewater, for example, landfill leachate or reject water after dewatering of sewage sludge, is treated in the main stream along with municipal wastewater. Despite the fact that reject water constitutes only a few percent of the total wastewater treatment plant (WWTP) flow rate, it contributes much a higher percentage of the nitrogen load in raw wastewater because it is rich in nitrogenous substances (Bernat et al. 2013). This causes a drop in the $\mathrm{COD} / \mathrm{N}$ ratio in the influent, and consequently a decrease in nitrogen removal effectiveness in conventional denitrification. In contrary, leachate from aerobic stabilization or composting contains not only a high concentration of nitrogen compounds but also high organics concentrations; thus, it makes a large contribution to the nitrogen and organics loads in raw wastewater, and creates a high COD/N ratio in the influent. This may positively affect nitrogen removal in a one-reactor system, for example, an SBR. However, it can negatively affect nitrification in a suspended activated sludge system because nitrifying bacteria grow slowly and are sensitive to the external conditions. To address this problem, not only suspended biomass but also biomass attached to carriers can be used. The advantages of such systems include high biomass concentrations, simultaneous nitrification and denitrification (SND), and resistance to nitrogen shock loading and other environmental changes. Although there have been many studies concerning the treatment of different kinds of wastewater with suspended and immobilized biomass, the novelty of the study is how the presence of carriers will affect the effectiveness and kinetics of pollutant removal from nitrogen- and organic-rich leachate from aerobic stabilization of OFMSW. Interest in this leachate has only recently begun to increase, and for this reason, its treatment has not been widely investigated.

Thus, the objective of the study (northeast of Poland, 2019/2020) was to determine the effectiveness and kinetics of organics and nitrogen removal from real leachate from aerobic stabilization of OFMSW in the main stream of the treatment in sequencing batch biofilm reactors (SBBRs). To compare the effectiveness of leachate treatment by different types of technical biocenoses, one reactor was operated with the conventional activated sludge process, and two reactors were supported by the addition of two types of carriers. It was found that both, floating and submerged carriers allowed suspended and attached biomass to coexist.

\section{Materials and methods}

\section{The leachate from aerobic stabilization of OFMSW}

The real leachate used in the experiment was collected from the municipal solid waste treatment plant located in northeastern Poland. In the technological line of this mechanical-biological treatment plant, a rotating drum is installed, which separates the waste into three fractions: the small fraction $(0-80 \mathrm{~mm})$, the medium fraction $(80-300 \mathrm{~mm})$ and the large fraction $(>300 \mathrm{~mm})$. The small fraction is biologically treated in three-stage aerobic stabilization. In first stage, ca. 4 weeks of biological treatment, intensive stabilization takes place in covered modules equipped with oxygen, humidity and temperature control systems. This is followed by maturation of the product in covered aerated windrows, and finally, maturation in open turned windrows. Leachate is produced at each stage of aerobic stabilization and gathered in a common drainage system. The characteristics of the real leachate are presented in Table 1. 


\section{The composition of the synthetic wastewater and the mixture of the leachate and wastewater}

The synthetic wastewater used in this study contained $\mathrm{CH}_{3} \mathrm{COONa}-150 \mathrm{mg} / \mathrm{L}$, urea- $60 \mathrm{mg} / \mathrm{L}, \mathrm{NH}_{4} \mathrm{Cl}-38 \mathrm{mg} / \mathrm{L}$, $\mathrm{Na}_{2} \mathrm{HPO}_{4} \cdot 12 \mathrm{H}_{2} \mathrm{O}-46.2 \mathrm{mg} / \mathrm{L}, \mathrm{NaCl}-10.1 \mathrm{mg} / \mathrm{L}, \mathrm{KCl}-$ $4.7 \mathrm{mg} / \mathrm{L}, \mathrm{CaCl}_{2} \cdot 2 \mathrm{H}_{2} \mathrm{O}-4.7 \mathrm{mg} / \mathrm{L}, \mathrm{MgSO}_{4} \cdot 7 \mathrm{H}_{2} \mathrm{O}-16.7 \mathrm{mg} / \mathrm{L}$, $\mathrm{NaHCO}_{3}-243.3 \mathrm{mg} / \mathrm{L}, \mathrm{Na}_{2} \mathrm{CO}_{3}-162.2 \mathrm{mg} / \mathrm{L}$; and $\mathrm{FeCl}_{3} \cdot 6 \mathrm{H}_{2} \mathrm{O}, \mathrm{ZnSO}_{4}, \mathrm{MnSO}_{4} \cdot \mathrm{H}_{2} \mathrm{O}$ and $\mathrm{CuSO}_{4}<0.2 \mathrm{mg} / \mathrm{L}$ (Coelho et al. 2000, modified). The characteristics of the synthetic wastewater are presented in Table 1. Real leachate from aerobic stabilization of OFMSW was diluted in a synthetic wastewater defined in the same proportion used in the mixture with the main stream of the treatment system. The content of the leachate in the influent was $10 \%(\mathrm{v} / \mathrm{v})$ (Table 1).

\section{Process configuration and system design}

The experiment was carried out in three laboratory-scale SBR-type reactors with a working volume of $2.5 \mathrm{~L}$ each. As seed sludge, activated sludge from the aerobic chamber of a local full-scale municipal wastewater treatment plant was used. In a control reactor $\left(R_{0}\right)$, suspended activated sludge was used, while in the other two reactors, plastic polyethylene commercial carriers were added that constituted ca. $30 \%$ of the working volume of the reactors. The ring-shape carriers had a diameter of $15 \mathrm{~mm}$ and length up to $10 \mathrm{~mm}$. In the $R_{\mathrm{FC}}$, carriers were less dense than water and floated at the top of the working volume of the reactor. In the $R_{\mathrm{SC}}$, carriers were more dense than water and were submerged at the bottom of the reactor. It means that in the $R_{\mathrm{FC}}$ and $R_{\mathrm{SC}}$ biomass was both suspended and immobilized.

The reactors working cycle was $24 \mathrm{~h}$ and consisted of the following phases: filling ( $5 \mathrm{~min})$, mixing $(3 \mathrm{~h})$, aeration
(20 h), and sedimentation and decantation (55 min). Each reactor was placed on a mechanical stirrer and was equipped with a fine-bubble aeration system located at the bottom of the reactor. The adjusted oxygen concentration during the aeration phase was ca. $2 \pm 0.2 \mathrm{mg} \mathrm{O}_{2} / \mathrm{L}$. The reactors were operated at room temperature $\left(20-22{ }^{\circ} \mathrm{C}\right)$.

During the period of adaptation of the microorganisms to the substrate conditions, the volumetric exchange ratio $\left(v_{\mathrm{er}}\right)$ was increased from $0.3 \mathrm{~d}^{-1}$ to $0.5 \mathrm{~d}^{-1}$. The initial biomass concentration of mixed liquor suspended solids (MLSS) was ca. $4.5 \mathrm{~g}$ MLSS/L, and mixed liquor volatile suspended solids (MLVSS) constituted ca. $70 \%$.

\section{Chemical analyses}

The following characteristics were monitored daily: $\mathrm{pH}$ and alkalinity, $\mathrm{BOD}_{5}$, COD, volatile fatty acids, orthophosphate, $\mathrm{TKN}$, ammonium, nitrites and nitrates. The concentrations of MLSS and MLVSS in the reactor were determined. In steadystate conditions, changes in the concentrations of COD, TKN, ammonium, nitrites and nitrates during the reactor cycle were measured. These analyses were performed according to APHA (1992). Dissolved oxygen (DO) concentration was measured with a ProODO optical oxygen meter (YSI Environmental).

The kinetic parameters were obtained by nonlinear regression analysis with Statistica software, version 13.3 (StatSoft). The 1st model used to determine the kinetics of BOD was described by the following equation:

$C_{t, \mathrm{BOD}_{20}}=C_{0, \mathrm{BOD}_{20}} \cdot\left(1-e^{k_{\mathrm{BOD}_{20}} \cdot t}\right)$,

where $C_{t: \mathrm{BOD} 20}\left(\mathrm{mg} \mathrm{O}_{2} / \mathrm{L}\right)$ is the cumulative $\mathrm{BOD}_{20}$ during 20-day $(t)$ measurements; $C_{0 ; \mathrm{BOD} 20}\left(\mathrm{mg} \mathrm{O}_{2} / \mathrm{L}\right)$ is the maximal
Table 1 Characteristics of the real leachate from aerobic stabilization of OFMSW, synthetic wastewater and a mixture of the leachate and wastewater $(1: 10 ; \mathrm{v} / \mathrm{v})$

\begin{tabular}{|c|c|c|c|c|}
\hline Characteristic & Unit & Leachate & Municipal wastewater & $\begin{array}{l}\text { Mixture of the } \\
\text { leachate and waste- } \\
\text { water }\end{array}$ \\
\hline $\mathrm{pH}$ & - & $8.3 \pm 0.1$ & $9.2 \pm 0.1$ & $9.1 \pm 0.1$ \\
\hline COD & $\mathrm{mg} \mathrm{O}_{2} / \mathrm{L}$ & $15,450.0 \pm 120.0$ & $405.0 \pm 10.0$ & $1909.0 \pm 17.0$ \\
\hline $\mathrm{BOD}_{5}$ & $\mathrm{mg} \mathrm{O}_{2} / \mathrm{L}$ & $8962.0 \pm 25.0$ & $388.0 \pm 5.0$ & $1245.0 \pm 10.0$ \\
\hline $\mathrm{BOD}_{20}$ & $\mathrm{mg} \mathrm{O}_{2} / \mathrm{L}$ & $13,690.0 \pm 43.0$ & $402.0 \pm 8.0$ & $1670.0 \pm 11.0$ \\
\hline Total Kjeldahl nitrogen & mg TKN/L & $1268.8 \pm 11.5$ & $78.8 \pm 2.5$ & $168.7 \pm 2.1$ \\
\hline Ammonium nitrogen & 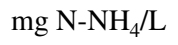 & $406.5 \pm 7.8$ & $44.2 \pm 1.1$ & $80.4 \pm 2.2$ \\
\hline Organic nitrogen & $\mathrm{mg} \mathrm{N}_{\text {org }} / \mathrm{L}$ & $862.8 \pm 6.4$ & $34.5 \pm 1.5$ & $88.3 \pm 6.1$ \\
\hline Orthophosphate & $\mathrm{mg} \mathrm{P}-\mathrm{PO}_{4} / \mathrm{L}$ & $47.6 \pm 2.1$ & $8.7 \pm 0.8$ & $12.6 \pm 0.6$ \\
\hline Volatile fatty acids & $\mathrm{mg} / \mathrm{L}$ & $8742.0 \pm 20.2$ & $223.0 \pm 5.0$ & $1075.0 \pm 12.0$ \\
\hline Alkalinity & $\mathrm{meq} / \mathrm{L}$ & $166.4 \pm 3.5$ & $16.9 \pm 2.1$ & $31.9 \pm 3.4$ \\
\hline $\mathrm{BOD}_{5} / \mathrm{COD}$ & - & 0.58 & 0.96 & 0.65 \\
\hline $\mathrm{BOD}_{20} / \mathrm{COD}$ & - & 0.89 & 0.99 & 0.87 \\
\hline $\mathrm{COD} / \mathrm{TKN}$ & - & 12.18 & 5.14 & 11.37 \\
\hline $\mathrm{BOD}_{20} / \mathrm{TKN}$ & - & 10.80 & 5.11 & 8.55 \\
\hline
\end{tabular}


$\mathrm{BOD}_{20} ; k_{\mathrm{O} 2}\left(\mathrm{~d}^{-1}\right)$ is the constant of oxygen consumption rate for oxidation of BOD compounds. From 1st model equation, the initial rate of oxygen consumption for BOD oxidation can be determined as follows $r_{\mathrm{O} 2}=C_{0 ; \mathrm{BOD} 20}{ }^{\circ} k_{\mathrm{O} 2}$.

\section{Results and discussion}

\section{Characteristics of leachate from aerobic stabilization of OFMSW}

Currently, in Poland, mechanical-biological treatment is used for processing mixed municipal solid waste (MSW), in which the small organic fraction $(0-80 \mathrm{~mm})$ is biologically processed. The commonly used process is aerobic stabilization during which nitrogen- and organic-rich leachate is generated (Romero et al. 2013; Liu et al. 2015). According to the literature, the concentration of COD in leachate from composting/aerobic stabilization ranges between 0.08 and $185 \mathrm{~g} \mathrm{O}_{2} / \mathrm{L}$ (Hashemi and Khodabakhshi 2016). Trujillo et al. (2006) found that dissolved COD concentrations in the leachate from composting two organic wastes (sewage sludge and the organic fraction of municipal solid wastes) reached $120 \mathrm{~g} \mathrm{O}_{2} / \mathrm{L}$. The average COD concentration is higher in leachate from MSW than in leachate from yard and green waste. This can be explained by the lower biodegradability of yard and green waste, which contains a large proportion of cellulosic biomass (Roy et al. 2018).

The leachate used in the present study, collected from the drainage system of a plant that biologically treated OFMSW, was a mixture of leachate from the reactors and that from covered and open windrows. It had an organics (as COD) concentration of ca. $15.5 \mathrm{~g} \mathrm{O}_{2} / \mathrm{L}$, whereas its TKN concentration was ca. $1300 \mathrm{mg} / \mathrm{L}$, and its ammonium concentration comprised ca. $30 \%$ of TKN.

To evaluate the biodegradability of organics in the leachate, the content of easily biodegradable organic compounds, expressed as $\mathrm{BOD}$, the $\mathrm{BOD} / \mathrm{COD}$ ratio and the rate constant of oxygen consumption $\left(k_{\mathrm{O} 2}\right)$ were determined. A BOD/COD ratio less than 0.1 indicates difficult-to-biodegrade organics, whereas ratios above 0.5 indicate easily biodegradable organics (Krogmann and Woyczechowski 2000; Foo and Hameed 2009; Tatsi and Zouboulis 2002). A 1st-order model was used to describe the BOD of the leachate after aerobic stabilization of OFMSW, synthetic wastewater and a mixture of leachate and wastewater (Fig. 1). This constant depends on the course of oxygen consumption during biodegradation of easily biodegradable compounds (expressed as BOD) and is thus affected by the $\mathrm{BOD}$ value. Moreover, the value of $k_{\mathrm{O} 2}$ influences primarily the rate at which the organic substances present in wastewater can be biologically oxidized. For example, values of $k_{\mathrm{O} 2}$ are much higher with raw municipal wastewater than with wastewater after biological treatment $\left(0.1-0.2 \mathrm{~d}^{-1}\right)$. With some industrial wastewaters or with leachate from old landfill sites, which
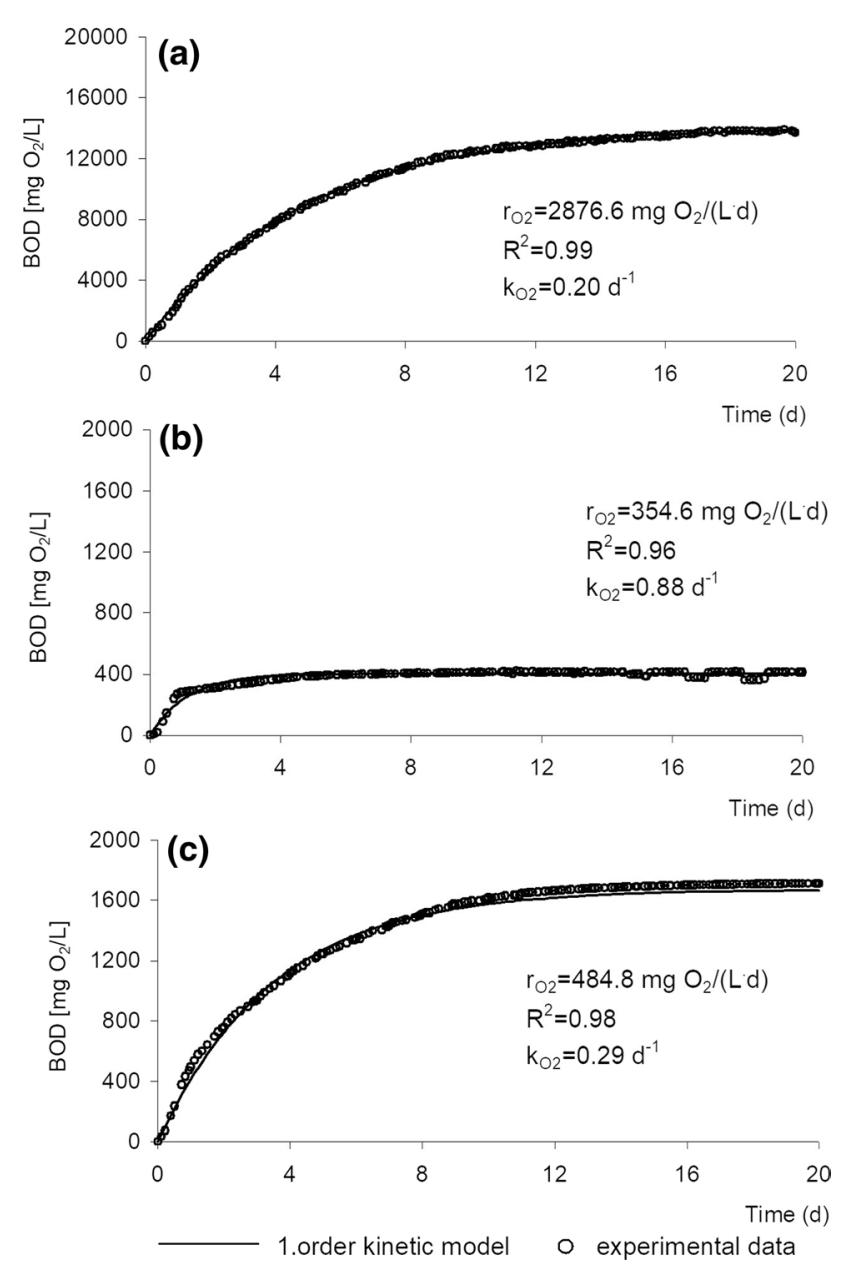

Fig. 1 Biochemical oxygen demands (BOD) for oxidation of organics in $\mathbf{a}$ the leachate from aerobic stabilization of the OFMSW, $\mathbf{b}$ synthetic wastewater, $\mathbf{c}$ mixture of both liquids; from the equations of the 1st-order models the rate of oxygen consumption for the organics (as BOD) oxidation $\left(r_{\mathrm{O} 2}\right)$ and the constant of oxygen consumption rate $\left(k_{\mathrm{O} 2}\right)$ were shown

contain difficult-to-biodegrade compounds, $k_{\mathrm{O} 2}$ values can be lower than $0.2 \mathrm{~d}^{-1}$ (Pitter and Chudoba 1990). Both the value of $k_{\mathrm{O} 2}$ and that of $\mathrm{BOD}$ (in $\mathrm{mg} / \mathrm{L}$ ) should be given together for complete characterization of the biodegradability of the substrate. In the present study, the value of $k_{\mathrm{O} 2}$ of the leachate from aerobic treatment of OFMSW was ca. $0.2 \mathrm{~d}^{-1}$, which would classify it as a substrate that is difficult to biodegrade. However, the $\mathrm{BOD}_{5}$ of the leachate was $8962.5 \mathrm{mg} \mathrm{O}_{2} / \mathrm{L}$. This was merely ca. $65 \%$ of the $\mathrm{BOD}_{20}$ value. The $\mathrm{BOD}_{7}$ was 1.2 -times higher than the $\mathrm{BOD}_{5}$ value, and $\mathrm{BOD}$ continued to increase, reaching 13,690.6 $\pm 43.5 \mathrm{mg} \mathrm{O} / \mathrm{L}$ after 20 days (Fig. 1). Therefore, despite the low $k_{\mathrm{O} 2}$ value, the $\mathrm{BOD}_{5} / \mathrm{COD}$ ratio of 0.58 and the $\mathrm{BOD}_{20} / \mathrm{COD}$ ratio of 0.89 indicated that the leachate had a high content of biodegradable compounds and was susceptible to biodegradation. However, the $\mathrm{BOD}_{5} / \mathrm{COD}$ ratio lower than $\mathrm{BOD}_{20} / \mathrm{COD}$ in the leachate at simultaneously low $k_{\mathrm{O} 2}$ indicates that microorganisms need longer time to decompose of 
the complex organic compounds in comparison with organic compounds present in the wastewater with both high $k_{\mathrm{O} 2}$ value and BOD/COD. The presence of a high content of organics in leachate from aerobic stabilization results from the breakdown of large and complex organic matter of OFMSW into simpler substances during transferring to the liquid phase through solid-liquid mass transfer. However, the organic macromolecules present in the leachate, at the beginning of the BOD measurements, can still be non-readily absorbable and degradable. Numerous microbes secrete different enzymes, which cleave the complex macromolecules from leachate into simpler forms. Due to the hydrolyses and the activity of extracellular enzymes, carbohydrates, lipids or proteins, which are inaccessible to microorganisms in their present forms, can be converted into sugars, long chain fatty acids and amino acids (Henze and Mladenovski 1991). After they are broken down into smaller components, they can be utilized and diffuse through the cell membranes. The time necessary for degradation and diffusion may cause that the $\mathrm{BOD}_{5} / \mathrm{COD}$ ratio is lower than the $\mathrm{BOD}_{20} / \mathrm{COD}$ ratio. Thus, when determining the content of biodegradable organics (as BOD) in some organic substrates, such as leachate from aerobic treatment of OFMSW, the time of measurement should be extended to 20 days.

In contrast, in the synthetic wastewater in which the organics came from acetate, the $k_{\mathrm{O} 2}$ value was higher than $0.8 \mathrm{~d}^{-1}$. The $\mathrm{BOD}_{5}$ value was almost equal to the $\mathrm{BOD}_{20}$ value, and it corresponded to almost $99 \%$ of the all organic compounds in the wastewater (as COD, ca. $400 \mathrm{mg} / \mathrm{L}$ ) which would classify it as a readily biodegradable substrate. Although the share of the real leachate from aerobic stabilization of OFMSW was $10 \%$ in the mixture with the synthetic wastewater $(\mathrm{v} / \mathrm{v})$, it strongly affected the $k_{\mathrm{O} 2}$ value. The $k_{\mathrm{O} 2}$ value for the mixture increased to ca. $0.3 \mathrm{~d}^{-1}$. However, the $\mathrm{BOD}_{5} / \mathrm{COD}$ ratio in the mixture increased to 0.65 indicating that the contribution of the organic compounds more susceptible to biodegradation in the mixture was higher and the time needed for biodegradation shortened in comparison with the real leachate.

One more parameter that should be taken into consideration in biological treatment is the COD/TKN ratio (BOD/TKN). It influences the growth of autotrophic and heterotrophic microorganism, causes the competition between their populations and therefore defines activated sludge composition. Too high COD/N ratio may cause oxygen depletion problems and predomination of heterotrophs which in consequence cause undesirable nitrification limitation. However, for an effective denitrification, the influent $\mathrm{COD} / \mathrm{N}$ ratio should be higher than 7.1 (Carrera et al. 2003), bearing in mind a $\mathrm{BOD}_{5} / \mathrm{COD}$ ratio of $0.5-0.6$. It should be emphasized that in a one-stage reactor, a part of organic compounds is used for biomass synthesis and is easily oxidized under aeration conditions. When denitrification is carried out in a separate chamber, and commercially available highly biodegradable compounds, like acetic acid or methanol, are used as carbon sources, the $\mathrm{COD} / \mathrm{N}$ ratio can be lower. For example, Torà et al. (2011) showed effective denitritation with an ethanol as a carbon source at $\mathrm{COD} / \mathrm{N}$ ratio of 3.0. In contrast, the $\mathrm{COD} / \mathrm{N}$ ratio may need to be higher when waste products are used as a carbon source. Fernández-Nava et al. (2010) indicated that the optimum $\mathrm{COD} / \mathrm{N}$ ratios for the denitrification step were 5.5-6.5 for the sugar-rich waste carbon sources and ca. 4.6 for the lactic-acid-rich waste carbon source.

Some kinds of wastewater, such as reject water after dewatering of sewage sludge, old landfill leachate or anaerobic digestate, often disturb the $\mathrm{COD} / \mathrm{N}$ ratio in the main stream of the treatment system (Bernat et al. 2013; Pei et al. 2018; Xie et al. 2018) because in their composition nitrogen compounds predominate over organic compounds. Thus, the insufficient COD in these wastewaters means disturbances in nitrogen removal. In contrast, leachate from composting/aerobic stabilization increases the $\mathrm{COD} / \mathrm{N}$ ratio in the main stream of treatment because of its very high content of organic compounds. The leachate used in this study had a COD/TKN ratio over 12 and a $\mathrm{BOD}_{20} / \mathrm{TKN}$ ratio of almost 11. When the content of leachate in the mixture of leachate and synthetic wastewater was $10 \%$, the COD/TKN and $\mathrm{BOD}_{20} / \mathrm{TKN}$ ratios were above 11 and ca. 8.5, respectively. The BOD/COD and COD/TKN ratios indicated that the conditions would be favorable for nitrogen removal in one-stage sequencing batch biofilm reactors. These values also indicated that the mixture was highly susceptible to degradation by microorganisms of activated sludge and that biological treatment with activated sludge can be a good solution for treating leachate from aerobic stabilization of OFMSW.

\section{The effectiveness of pollutant removal from the leachate from aerobic stabilization of OFMSW in SBBRs}

The volumetric exchange ratio $\left(v_{\text {er }}\right)$ was increased over 30 days to the planned value of $0.5 \mathrm{~d}^{-1}$ and then it was maintained up to day 80 of the experiment. In the mixture of leachate and wastewater supplied to the reactors, the alkalinity and $\mathrm{pH}$ were $32 \mathrm{meq} / \mathrm{L}$ and $9.1 \mathrm{pH}$, respectively. There was no $\mathrm{pH}$ correction during the experiment. In the effluent from the $R_{0}$, the average alkalinity was $21 \mathrm{meq} / \mathrm{L}$ and the $\mathrm{pH}$ was 9.6. These values were the same as those in the effluents from $R_{\mathrm{FC}}$ and $R_{\mathrm{SC}}$. In the mixture of leachate and wastewater, the COD concentration was $1910 \pm 17 \mathrm{mg} / \mathrm{L}$; therefore, at the planned $v_{\mathrm{er}}$ of $0.5 \mathrm{~d}^{-1}$, at the beginning of the SBR cycle, the COD concentration was ca. $960 \mathrm{mg} / \mathrm{L}$. The concentration of COD in the effluent from each reactor was similar, averaging about $250 \mathrm{mg} / \mathrm{L}$ (Fig. 2).

The $\mathrm{BOD}_{5}$ concentration differed between the reactors; it was lowest in the effluent from $R_{0}(10.7 \pm 0.9 \mathrm{mg} / \mathrm{L})$ and highest in the effluent from $R_{\mathrm{FC}}(15.3 \pm 0.9 \mathrm{mg} / \mathrm{L})$ (Table 2). 


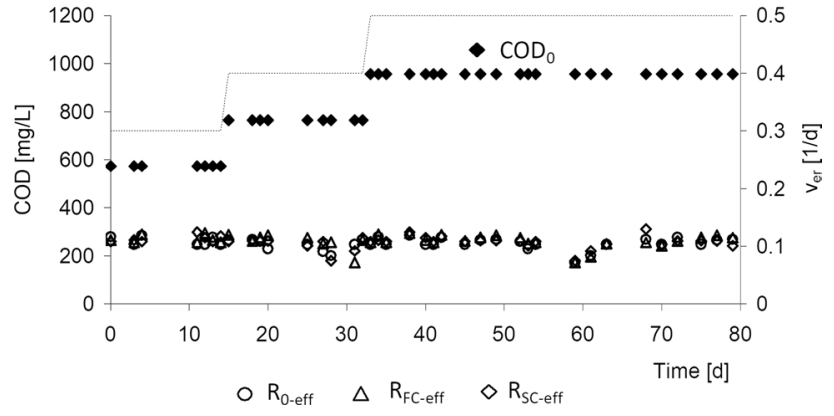

Fig. 2 Changes in organic compounds (as COD) concentration in the effluent from $R_{0}, R_{\mathrm{FC}}$ and $R_{\mathrm{SC}}$, and COD concentration at the beginning of the cycle $\left(\mathrm{COD}_{0}\right)$; dotted line indicates increasing $v_{\mathrm{er}}$

Thus, in the effluent from all the reactors, more than $95 \%$ of the COD was in the form of difficult-to-degrade compounds, also known as the inert fraction of organics. Christensen et al. (1998) reported that $33 \%$ of the dissolved organic matter in landfill leachates had low biodegradability. Thus, a portion of the organic compounds remains in the effluent. To meet strict quality standards for direct discharge of leachate into surface water, integrated methods of treatment would be required, i.e., a combination of chemical, physical and biological steps to improve the quality of the effluent from the three reactors in this study. For example, the combined system of adsorption on powdered activated carbon (PAC)-ultrafiltration (UF, cutoff of $5 \mathrm{kDa}$ ) was used for the treatment of leachate from the stabilized landfill of the low $\mathrm{BOD}_{5} / \mathrm{COD}$ ratio (0.11) (Kulikowska et al. 2019). Adsorption alone did not effectively remove COD (12.9\% and $34.5 \%$, depending on PAC dose). In UF alone, COD removal efficiency was also low (46.5\%). Similarly, UF was reported to remove 50\% (Bohdziewicz et al. 2001) or $38 \%$ (cutoff of $50 \mathrm{kDa}$ ) and $66 \%$ (cutoff of $1 \mathrm{kDa}$ ) of organics from leachate (Renou et al. 2009). The combined system of PAC-UF increased the COD removal efficiency to about $86 \%$ (Kulikowska et al. 2019). This was because organic compounds, including humic substances, were first adsorbed on PAC and then PAC particles blocked membrane pores, which made effective pore sizes of membrane smaller, thus allowing the retention of substances of small molecular weight. The other solution could be the use of high-pressure membrane technique, such as nanofiltration (NF). For example, Trebouet et al. (2001) achieved 74-80\% of refractory COD removal from leachate characterized by $\mathrm{BOD}_{5} / \mathrm{COD}$ of 0.03 and 0.10 . In the present study, the effluent from each reactor contained about $30 \mathrm{mg}$ TSS/L. Therefore, the pretreatment prior to NF would be necessary to remove potential foulants like suspended and colloidal particles.

TKN can range from 7.2 to $18,570 \mathrm{mg} \mathrm{N} / \mathrm{L}$ in leachate from composting/aerobic stabilization, and the $\mathrm{NH}_{4}^{+} / \mathrm{TKN}$ ratio is commonly ca. 0.6 . Domestic wastewater typically contains $\sim 60 \%$
Table 2 The average parameters of the effluents from reactors operated at $v_{\text {er }} 0.5 \mathrm{~d}^{-1}$

\begin{tabular}{|c|c|c|c|c|}
\hline $\begin{array}{l}\text { Character- } \\
\text { istic }\end{array}$ & Unit & $R_{0 \text {-eff }}$ & $R_{\mathrm{FC} \text {-eff }}$ & $R_{\mathrm{SC}-\text { eff }}$ \\
\hline $\mathrm{pH}$ & - & $9.6 \pm 0.1$ & $9.6 \pm 0.1$ & $9.6 \pm 0.1$ \\
\hline COD & $\mathrm{mg} \mathrm{O}_{2} / \mathrm{L}$ & $252.0 \pm 26.0$ & $260.0 \pm 29.0$ & $258.0 \pm 27.0$ \\
\hline $\mathrm{BOD}_{5}$ & $\mathrm{mg} \mathrm{O}_{2} / \mathrm{L}$ & $11.0 \pm 1.0$ & $15.0 \pm 1.0$ & $14.0 \pm 1.0$ \\
\hline $\mathrm{BOD}_{7}$ & $\mathrm{mg} \mathrm{O}_{2} / \mathrm{L}$ & $12.0 \pm 1.0$ & $16.0 \pm 1.0$ & $15.0 \pm 1.0$ \\
\hline $\mathrm{N}-\mathrm{NO}_{3}$ & $\mathrm{mg} \mathrm{N}-\mathrm{NO}_{3} / \mathrm{L}$ & $50.2 \pm 4.7$ & $40.2 \pm 6.2$ & $24.1 \pm 4.9$ \\
\hline $\mathrm{N}-\mathrm{NO}_{2}$ & $\mathrm{mg} \mathrm{N}-\mathrm{NO}_{2} / \mathrm{L}$ & $0.2 \pm 0.2$ & $0.2 \pm 0.2$ & $0.2 \pm 0.2$ \\
\hline TKN & $\mathrm{mg} \mathrm{N}_{\mathrm{TKN}} / \mathrm{L}$ & $9.7 \pm 1.1$ & $10.1 \pm 0.6$ & $9.8 \pm 0.5$ \\
\hline $\mathrm{N}-\mathrm{NH}_{4}$ & $\mathrm{mg} \mathrm{N}-\mathrm{NH}_{4} / \mathrm{L}$ & $1.3 \pm 0.3$ & $1.4 \pm 0.4$ & $1.3 \pm 0.5$ \\
\hline $\mathrm{P}-\mathrm{PO}_{4}$ & $\mathrm{mg} \mathrm{P}-\mathrm{PO}_{4} / \mathrm{L}$ & $0.9 \pm 0.5$ & $1.0 \pm 0.8$ & $1.1 \pm 0.6$ \\
\hline Alkalinity & $\mathrm{meq} / \mathrm{L}$ & $21.5 \pm 1.4$ & $20.9 \pm 2.2$ & $21.5 \pm 1.5$ \\
\hline
\end{tabular}

Effectiveness of organics removal, nitrification, denitrification and nitrogen removal

\begin{tabular}{lllll}
$\mathrm{E}_{\mathrm{COD}}$ & $\%$ & $87.0 \pm 2.1$ & $86.5 \pm 1.6$ & $86.5 \pm 1.6$ \\
$\mathrm{E}_{\mathrm{BOD}}$ & $\%$ & $98.6 \pm 1.9$ & $96.5 \pm 2.0$ & $98.2 \pm 1.4$ \\
$\mathrm{E}_{\mathrm{N}-\mathrm{NH} 4}$ & $\%$ & $88.9 \pm 1.5$ & $89.3 \pm 1.5$ & $89.2 \pm 1.6$ \\
$\mathrm{E}_{\mathrm{nit}}$ & $\%$ & $84.2 \pm 2.0$ & $84.2 \pm 1.8$ & $84.3 \pm 1.4$ \\
$\mathrm{E}_{\mathrm{D}}$ & $\%$ & $43.2 \pm .1 .0$ & $51.9 \pm 1.3$ & $67.4 \pm 2.3$ \\
$\mathrm{E}_{\mathrm{N}}$ & $\%$ & $57.7 \pm 1.3$ & $63.7 \pm 1.7$ & $73.0 \pm 1.2$ \\
\hline
\end{tabular}

$E_{\text {nit }}-$ nitrification efficiency, calculated based on the initial concentration of nitrogen that may have been oxidized (i.e., ammonium, and organic nitrogen which has been ammonified, after subtracting nitrogen for biomass synthesis) and ammonium in the effluent, $E_{\mathrm{N}-\mathrm{NH} 4}$ effectiveness of ammonium removal that was oxidized in nitrification and used for biomass synthesis; $E_{\mathrm{D}}$-denitrification efficiency, calculated based on the initial concentration of nitrogen that could have been denitrified and the concentration of nitrate and nitrite in the effluent, $E_{\mathrm{N}}$-effectiveness of nitrogen removal, calculated based on the amount of nitrogen denitrified, used for biomass synthesis and available TKN (taking into consideration the amount of TKN in the effluent)

ammonium $\mathrm{N}$ and $40 \%$ organic $\mathrm{N}$, which means that leachate and municipal wastewater are similar in terms of bioavailability (Stefanakis et al. 2014; Tas et al. 2009). Forty percent of nitrogen in the leachate that is in the form of organic nitrogen need to be converted into ammonium, which is the form of nitrogen that is most readily available to microorganisms. In the present study, TKN in the leachate comprised mainly organic nitrogen and only ca. $30 \%$ ammonium. In the wastewater, which constituted $90 \%$ of the influent stream, the $\mathrm{N}-\mathrm{NH}_{4}{ }^{+} / \mathrm{TKN}$ ratio was ca. 0.5. Thus, at the beginning of the cycle, the TKN concentration was ca. $80 \mathrm{mg} / \mathrm{L}$ and that of ammonium was $40 \mathrm{mg} / \mathrm{L}$. In other words, a large portion of TKN consisted of nitrogen that required ammonification to convert it into ammonium, which is the first step in nitrogen transformation by microorganisms, and it takes place under both aerobic and anaerobic conditions. Microorganisms derive energy during metabolic transformation of organic nitrogen to ammonium. In ammonification, $\mathrm{NH}_{2}$ groups are converted into ammonia or its ionic form, ammonium $\left(\mathrm{NH}_{4}{ }^{+}\right)$, as an end product. During wastewater treatment ammonium can be easily 
synthesized into bacterial biomass and/or undergoes nitrification. The rate of ammonification is higher than that of nitrification (Vymazal et al. 2006, 2007). It was observed that, in steady-state conditions at a $v_{\text {er }}$ of $0.5 \mathrm{~d}^{-1}$, the TKN concentration in the effluent was ca. $10 \mathrm{mg} / \mathrm{L}$, of which ca. $15 \%$ was ammonium. This means that, instead of the $40 \mathrm{mg} \mathrm{N}-\mathrm{NH}_{4} / \mathrm{L}$ that was present at the beginning of the cycle, ca. $70 \mathrm{mg} \mathrm{N}-\mathrm{NH}_{4} / \mathrm{L}$ could be oxidized or used for biomass synthesis. This also means that the effectiveness of ammonification was ca. $76 \%$, and few milligrams of organic nitrogen remained in the effluent.

In the present study, in each reactor, regardless of whether they contained carriers or not, the highest concentration of ammonium in the effluents was observed in the adaptation phase ( $v_{\text {er }}$ from 0.3 to $0.5 \mathrm{~d}^{-1}$ ) (Fig. 3).

The concentrations of ammonium reached up to $18 \mathrm{mg} \mathrm{N}-\mathrm{NH}_{4} / \mathrm{L}$ in $R_{\mathrm{SC}}$, while during this time in $R_{0}$ and $R_{\mathrm{FC}}$, it did not exceed $5 \mathrm{mg} \mathrm{N}-\mathrm{NH}_{4} / \mathrm{L}$. In the adaptation period, not only nitrates but also nitrites were formed as intermediate nitrification products. This means no complete nitrification took place in this time. Around 3 weeks were needed for microbial adaptation. After 20 days of the experiment, the ammonium concentration stabilized and was no higher than $1.4 \mathrm{mg} \mathrm{N}-\mathrm{NH}_{4} / \mathrm{L}$ in all reactors. The nitrite concentrations in the effluent from all reactors were $0.2 \pm 0.2 \mathrm{mg} \mathrm{N}-\mathrm{NO}_{2} / \mathrm{L}$, and nitrate predominated, indicating complete nitrification of ammonium to nitrate. From day 34 of the experiment, nitrate concentrations were stable. The highest average nitrate concentration, $50.2 \pm 4.7 \mathrm{mg} \mathrm{N}-\mathrm{NO}_{3} / \mathrm{L}$, was noted in the $R_{0}$ effluent, while the lowest (ca. 52\% lower) in the $R_{\mathrm{SC}}$ effluent (Table 2).

Two main processes responsible for nitrogen removal from wastewater are biological nitrification and denitrification. Nitrifiers (ammonium-oxidizing bacteria (AOB) and nitrite-oxidizing bacteria (NOB)) should comprise more than $5-8 \%$ of the biomass for ammonium oxidation to proceed ( $\mathrm{Li}$ et al. 2007). They obtain energy for growth by oxidizing either ammonia or nitrite; however, they are not closely related phylogenetically, and none of these organisms can oxidize both substrates. Two nitrification steps lead to a tight cross-feeding interaction and the frequently observed co-aggregation of AOB with NOB in nitrifying consortia (Arp and Bottomley 2006). Thus, to obtain complete nitrification, an AOB activity should precede the activity of NOB, without the inhibition of the second step. Commonly, nitrification proceeds at low organic loadings and at high dissolved oxygen concentration. In one-stage reactor, the first step of nitrification, ammonium oxidation, takes place simultaneously with organics oxidation or after the organic compounds are oxidized. Then, the oxygen concentration in wastewater starts to increase, allowing nitrite to nitrate oxidation.

Both AOB and NOB have slow growth rates and are sensitive to environmental factors such as toxic shocks, and changes in $\mathrm{pH}$ and temperature (Coskuner and Curtis 2002; Schmidt et al. 2003). To effectively maintain nitrifiers in the wastewater treatment system, biomass immobilization in attached growth
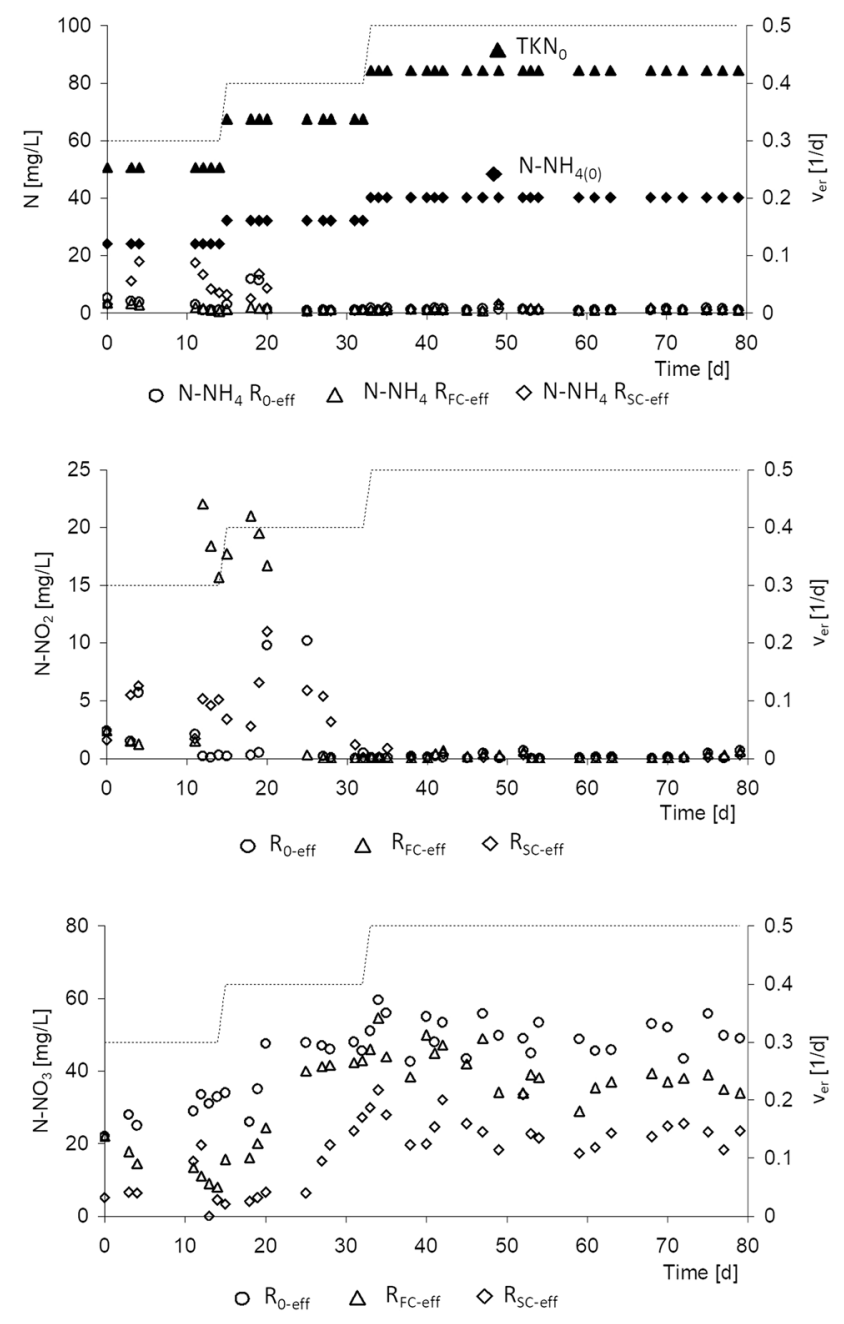

Fig. 3 Changes in nitrogen concentrations in the effluent from $R_{0}, R_{\mathrm{FC}}$ and $R_{\mathrm{SC}}$, and TKN and ammonium concentrations at the beginning of the cycle $\left(\mathrm{TKN}_{0}\right.$ and $\left.\mathrm{N}-\mathrm{NH}_{4(0)}\right)$; dotted line reflects increasing $v_{\text {er }}$

reactors has been suggested to improve nitrogen removal performance (Xiangli et al. 2008; Dong et al. 2016). The results of Artiga et al. (2005) proved the use of plastic carriers resulted in higher content of fraction of nitrifiers. In the present study, there was no problem to obtain complete nitrification during the treatment of leachate after aerobic stabilization in both control reactor with suspended biomass and in the reactors with immobilized biomass. Other advantages of attached biomass include a high biomass concentration, coexistence of nitrifiers and denitrifiers, resulting in SND. In recent years, in attached growth reactors for wastewater treatment, various natural and artificial carriers have been used. The latter can be made from polyethylene and polyurethane. Such carriers can improve the efficiency of long-term nitrification and denitrification and sustain microbial populations of slowly growing microorganisms (Daniel et al. 2009). Sirianuntapiboon et al. (2005) modified an SBR system by the addition of plastic media on the bottom of the reactor (SBBR). To treat milk industry wastewater 
$(7500 \pm 324 \mathrm{mg} \mathrm{COD} / \mathrm{L}, 120 \pm 2.8 \mathrm{mg} \mathrm{TKN} / \mathrm{L})$ at organic loadings increasing from 500 to $1340 \mathrm{mg} \mathrm{BOD} /(\mathrm{L} \cdot \mathrm{d})$, this modification increased the pollutants removal efficiencies, improved sludge quality, reduced the amount of excess sludge and also shortened the acclimatization period of the system. The effectiveness of pollutant removal decreased as the organic loading increased. Under the highest organic loading, efficiencies of $\mathrm{COD}, \mathrm{BOD}_{5}$ and TKN removal were $89.3 \pm 0.1 \%, 83.0 \pm 0.2 \%$ and $59.4 \pm 0.8 \%$, respectively, in the SBBR. In contrast, at the same organic loading, the efficiencies in the SBR were $87.0 \pm 0.2 \%, 79.9 \pm 0.3 \%$ and $48.7 \pm 1.7 \%$, respectively.

In the present study, at similar organic loadings as in the study by Sirianuntapiboon et al. (2005), regardless of whether the reactors contained carriers or not, the effectiveness of nitrification (84.2-84.3\%) and the removal effectiveness of COD (86.5-87.0\%), BOD (96.5-98.6\%) and $\mathrm{N}^{-\mathrm{NH}_{4}}(88.9-89.3 \%)$ did not differ. However, the presence of carriers and their type affected the effectiveness of denitrification $\left(\mathrm{E}_{\mathrm{D}}\right)$ and nitrogen removal $\left(\mathrm{E}_{\mathrm{N}}\right)$ (due to both denitrification and biomass synthesis). In $R_{0}$, the $\mathrm{E}_{\mathrm{D}}$ and $\mathrm{E}_{\mathrm{N}}$ were ca. $43.2 \%$ and $57.7 \%$, respectively. These results were similar to those reported for a conventional SBR by Sirianuntapiboon et al. (2005). In comparison with $R_{0}, \mathrm{E}_{\mathrm{D}}$ and $\mathrm{E}_{\mathrm{N}}$ increased 1.23- and 1.10-times, respectively, in $R_{\mathrm{FC}}$. The use of the submerged carriers increased $\mathrm{E}_{\mathrm{D}}$ and $\mathrm{E}_{\mathrm{N}}$ to $67.4 \%$ and $73.0 \%$, respectively (Table 2). The efficiencies of $\mathrm{COD}, \mathrm{BOD}_{5}$ and TKN removal obtained by Sirianuntapiboon et al. (2005) in an SBBR were slightly lower than those in the similarly constructed reactor, $R_{\mathrm{SC}}$, used in the present study. Le et al. (2018) tested concrete, sponge waste materials and commercial plastic materials as biomass carriers in attached growth reactors for the treatment of synthetic wastewater with an ammonium content of 40-80 $\mathrm{mg} \mathrm{N}-\mathrm{NH}_{4} / \mathrm{L}$ and much lower content of COD of 140-280 mg COD/L than in the present study. They found that, at a $\mathrm{C} / \mathrm{N}$ ratio of 3.5 , nitrogen removal efficiency was highest, $87 \%$, in the reactor with sponge carriers, whereas it decreased to $82 \%$ in the reactor with concrete, and to $76 \%$ in the reactor with commercial carriers. These values were higher than that obtained in the present study; however, it has to be emphasized that the COD/TKN ratio in the present study was much higher that could be unfavorable for autotrophic nitrifiers, especially when COD was abundant. Moreover, at high content of COD concentration, despite aeration, oxygen can be depleted for organics mineralization. The sponge waste materials investigated by Le et al. (2018) had high porosity and surface roughness. Moreover, biomass on the sponge carrier tolerated high ammonium loadings and retained excellent performance. Nitrification and denitrification occurred simultaneously, removing nitrogen in the sponge and the commercial carrier reactor. In the biofilms of a sponge reactor, there were DO gradients because of diffusion limitation (Kotlar et al. 1996). Nitrification took place at the aerobic layer of the sponge surface, whereas denitrification happened in the deeper layer of biofilm, in which there was an anoxic zone. However, in the concrete reactor, nitrification mainly occurred during the aeration phase and denitrification occurred in the non-aeration phase. Le et al. (2016) used corncob (biodegradable material) and concrete (nonbiodegradable material), as carriers in SBBRs treating synthetic domestic wastewater with ammonium concentration of $40 \mathrm{mg} / \mathrm{L}$, to improve the effectiveness of both nitrification and nitrogen removal. The corncob carriers were not only a media for biomass attachment but also a source of carbon for denitrification (up to 95\%); however, ammonium oxidation effectiveness was merely $60 \%$, and the turbidity of the effluent increased. In the reactor with concrete carriers, a $\mathrm{C} / \mathrm{N}$ ratio of 3.5 was required to achieve an effectiveness of ammonium and nitrogen removal of $95 \%$. The results of the other studies and of the present study indicate that, to improve the effectiveness of pollutant removal in a SBBR, the overall conditions, e.g., the COD/TKN ratio, oxygen conditions, and technological parameters including the type of carriers, should be taken into consideration.

\section{Changes in pollutant concentration during reactor cycle}

The changes in the concentrations of all nitrogen forms and DO concentration in wastewater are presented in Fig. 4. As mentioned, at the beginning of the cycle in all reactors, $70-80 \mathrm{mg} / \mathrm{L}$ of nitrogen was available to the microorganisms for biomass synthesis and nitrification. After taking into account the amount of nitrogen used for the biomass synthesis (ca. $10 \mathrm{mg} \mathrm{N} / \mathrm{L}$ ), the remained amount of ammonium was oxidized. However, it should be emphasized that, at the beginning of the cycle, half of the nitrates from the previous cycle was left. Thus, not only the oxidized form of nitrogen that was generated in the aeration phase (ammonium that was oxidized) was available to microorganisms responsible for nitrogen removal, but also nitrates from the previous cycle $\left(\mathrm{N}^{*}\right)$ (black dotted line in Fig. 4). During the reactor cycle, all transformations of nitrogen compounds took place in the mixing and aeration phases. These transformations involved ammonification, nitrogen use for biomass synthesis, nitrification and also heterotrophic denitrification or SND.

During the mixing phase in each reactor, regardless of whether they contained carriers or not, only small decrease in ammonium concentration was noted. In this phase, DO concentration did not exceed $0.15 \mathrm{mg}$ $\mathrm{O}_{2} / \mathrm{L}$ indicating anoxic conditions. It should be emphasized that in the reactors with carriers the content was lower $\left(0.10 \mathrm{mg} \mathrm{O}_{2} / \mathrm{L}\right)$ than in the control reactor. Ammonium removal started in the aeration phase and followed 0 -order kinetics. In $R_{0}$, ammonium was removed during $4 \mathrm{~h}$ of the aeration phase; after this time, its concentration remained at the same level to the end of the cycle. The rate of ammonium removal was $8.8 \mathrm{mg} \mathrm{N}-\mathrm{NH}_{4} /(\mathrm{L} \cdot \mathrm{h})$ (2.79 $\mathrm{mg} \mathrm{N}-\mathrm{NH}_{4} /(\mathrm{g}$ MLVSS$\left.\cdot h)\right)$. From $4^{\text {th }}$ hour of the reactor cycle, DO concentration increased rapidly to the adjusted value of ca. $2 \mathrm{mg} \mathrm{O}_{2} / \mathrm{L}$. 

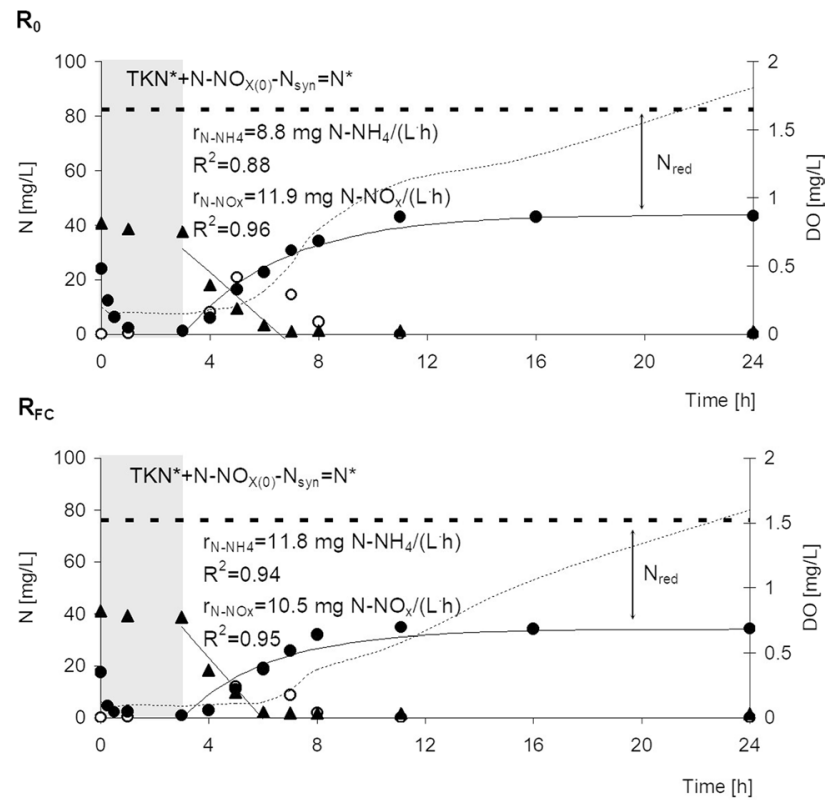

$\mathrm{R}_{\mathrm{sc}}$

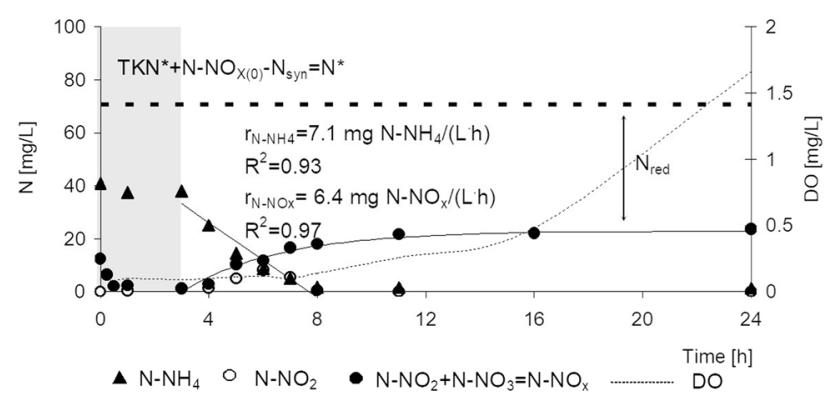

Fig. 4 Changes in concentrations of ammonium, nitrite, nitrate and DO during reactors at $v_{\mathrm{er}} 0.5 \mathrm{~d}^{-1}$, gray area reflects mixing phase; black dotted line indicates initial concentration of nitrogen $\left(\mathrm{N}^{*}\right)$ available for microorganisms (as a difference $\left(\mathrm{TKN}^{*}\right.$ ) between the TKN concentration at the beginning of the reactor cycle and TKN concentration in the effluent, increased by the amount of oxidized nitrogen forms at the beginning of the cycle $\left(\mathrm{N}-\mathrm{NO}_{x(0)}\right)$ and diminished by the amount of nitrogen for biomass synthesis $\left(\mathrm{N}_{\mathrm{syn}}\right) ; \mathrm{N}_{\text {red }}$ indicates the amount of nitrogen reduced by microorganisms during the cycle; the rates of ammonium removal $\left(r_{\mathrm{N}-\mathrm{NH} 4}\right)$ and the rate of the increase in oxidized nitrogen forms $\left(r_{\mathrm{N}-\mathrm{NO} x}\right)$ during aeration phase are given

In $R_{\mathrm{FC}}$ and $R_{\mathrm{SC}}$, during aeration phase, the increase in $\mathrm{DO}$ concentration was slower than in the control reactor. Despite aeration started, the oxygen depletion phase occurred during first hours of the phase (Fig. 4). The use of floating carriers in $R_{\mathrm{FC}}$ caused the time needed for ammonium removal to decrease to $3 \mathrm{~h}$ of the aeration phase. The rate of ammonium removal in the $R_{\mathrm{FC}}$ was the highest, $11.8 \mathrm{mg} \mathrm{N}-\mathrm{NH}_{4} /(\mathrm{L} \cdot \mathrm{h})$ (3.74 $\mathrm{mg} \mathrm{N}-\mathrm{NH}_{4} /(\mathrm{g}$ MLVSS$\cdot \mathrm{h})$ ). This indicated that in this reactor the oxygen depletion phase did not affected ammonium removal. In $R_{\mathrm{SC}}$, the time needed for ammonium removal was the longest ( $5 \mathrm{~h}$ of the aeration phase), and the rate of the process was the lowest (7.1 $\mathrm{mg} \mathrm{N}-\mathrm{NH}_{4} /(\mathrm{L} \cdot \mathrm{h}), 2.25 \mathrm{mg} \mathrm{N}-\mathrm{NH}_{4} /$ (g MLVSS $\cdot h)$ ). This resulted from the fact that the oxygen depletion phase was the longest and it reduced the rate of ammonium oxidation. Daily measurements of the changes in ammonium concentration confirmed that the concentration in all the effluents did not exceed $1.4 \mathrm{mg} \mathrm{N}-\mathrm{NH}_{4} / \mathrm{L}$.

Despite the aeration, oxygen depletion phase was noted, because oxygen was immediately used for ammonium and COD oxidation. Akin and Ugurlu (2005) indicated that, at a DO concentration lower than $1 \mathrm{mg} / \mathrm{L}$, nitrification can be carried out by heterotrophic nitrifying bacteria. In ammonium oxidation in many ecosystems, heterotrophs dominate over autotrophs. Heterotrophic nitrifying bacteria can grow much faster than autotrophic ones and are better adapted to lower DO levels (Zhao et al. 1999).

The studies concerning determination of the rate of ammonium removal were carried out with the use of different kind of substrates (for example, synthetic wastewater, landfill leachate or reject water) and at different initial ammonium content. Akin and Ugurlu (2005) indicated that in SBR treating synthetic wastewater with $50 \mathrm{mg} \mathrm{N}-\mathrm{NH}_{4} / \mathrm{L}$ and $400 \mathrm{mg} \mathrm{COD} / \mathrm{L}$ the effectiveness of COD and ammonium removal were $90-98 \%$ and $90-95 \%$, respectively. The rate of ammonium removal was $2.38 \mathrm{mg} \mathrm{N}-\mathrm{NH}_{4} /(\mathrm{g}$ MLVSS.h) and was similar to those obtained in the present study. In contrast, much higher rate of ammonium removal, $19 \mathrm{mg} \mathrm{N}-\mathrm{NH}_{4} /$ (g MLVSS·h), was found by Dosta et al. (2007) during the treatment of reject water from wastewater treatment plant (800-900 mg N-NH$/ 4,1500-2000 \mathrm{mg} \mathrm{COD/L}$ ) in the SBR. It should be emphasized that at the beginning of the cycle ammonium concentration exceeded $250 \mathrm{mg} / \mathrm{L}$. Almost 10-times higher initial concentration of ammonium was used in the study of Carrera et al. (2003). The authors carried out the treatment of the real industrial wastewater (4000-6000 $\mathrm{mg} \mathrm{N}-\mathrm{NH}_{4} / \mathrm{L}$ and 1200-1300 mg COD/L) and showed nitrification rates in aerated SBR, in a two-sludge system, in the ranges of 4.58-7.50 $\mathrm{mg} \mathrm{N}-\mathrm{NH}_{4} /(\mathrm{g} \mathrm{VSS} \cdot \mathrm{h})$.

Koc-Jurczyk and Jurczyk (2017) treated old landfill leachate (average pollutant concentrations were $4125 \mathrm{mg}$ $\mathrm{COD} / \mathrm{L}, 636 \mathrm{mg} \mathrm{BOD}{ }_{5} / \mathrm{L}\left(\mathrm{BOD}_{5} / \mathrm{COD}\right.$ ratio of 0.15$)$, $775 \mathrm{mg} \mathrm{N}-\mathrm{NH}_{4} / \mathrm{L}$ and $850 \mathrm{mg} \mathrm{TKN} / \mathrm{L}$ ) in three SBRs at $37^{\circ} \mathrm{C}$. SBR 1 contained suspended activated sludge, whereas two SBRs additionally contained foam carriers with different numbers of pores (30 in SBR2 and 15 in SBR3). The working cycle comprised mainly aeration $(23 \mathrm{~h})$, without mixing. The effectiveness of $\mathrm{BOD}_{5}$ removal exceeded $95 \%$, but most of the organics were hard-to-degrade, thus the content of COD in the effluents, $3727-3955 \mathrm{mg} / \mathrm{L}$, was much higher than in the present study. In SBR2, the $\mathrm{N}^{-\mathrm{NH}_{4}}$ removal efficiency was highest (77.6\%), and it was lowest in SBR1 (46.3\%); however, it should be mentioned that the ammonium content in the influent was ca. $800 \mathrm{mg} / \mathrm{L}$. Ammonium removal proceeded with 1st-order model (the rate of the process was $\left.50-68 \mathrm{mg} \mathrm{N}-\mathrm{NH}_{4} /(\mathrm{L} \cdot \mathrm{h})\right)$. These results are in contrast to those of the present study, in which the effectiveness of ammonium 
removal and nitrification did not depend on whether the reactors contained carriers or not. Moreover, in the present study, ammonium removal proceeded with 0 -order model and the rates of ammonium removal were several times lower, with a lower content of ammonium at the beginning of the cycle.

Ammonium removal in the present study was accompanied by an increase in the concentration of $\mathrm{N}-\mathrm{NO}_{x}$ (sum of $\mathrm{N}^{-\mathrm{NO}_{2}}$ and $\mathrm{N}-\mathrm{NO}_{3}$ ), which means that nitrification took place. During the initial 3-4 $\mathrm{h}$ of the aeration phase, nitrites were the main nitrification product, and their concentration increased. When ammonium was almost depleted, the nitrite concentration started to decrease, and nitrate was formed. The increase in $\mathrm{N}-\mathrm{NO}_{x}$ concentrations proceeded with 1st-order model. In $R_{0}$, the concentration of $\mathrm{N}-\mathrm{NO}_{x}$ increased at the highest rate $\left(r_{\mathrm{N}-\mathrm{NO} x}\right)$ of $11.9 \mathrm{mg} \mathrm{N}-\mathrm{NO}_{x} /(\mathrm{L} \cdot \mathrm{h})$, after $8 \mathrm{~h}$ of aeration (11 h of the cycle) this concentration stabilized, reaching ca.

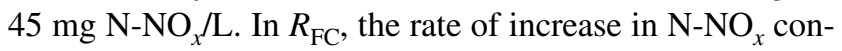
centration $\left(r_{\mathrm{N}-\mathrm{NO} x}\right)$ was slightly lower $\left(10.5 \mathrm{mg} \mathrm{N}-\mathrm{NO}_{x} /(\mathrm{L} \cdot \mathrm{h})\right)$, and the final concentration was ca. $35 \mathrm{mg} \mathrm{N}-\mathrm{NO}_{x} / \mathrm{L}$ (after $10 \mathrm{~h}$ of the cycle). In $R_{\mathrm{SC}}$, the final content of $\mathrm{N}^{-\mathrm{NO}_{x}}$, ca. $20 \mathrm{mg} / \mathrm{L}$, and the rate of the increase in $\mathrm{N}^{-\mathrm{NO}_{x}}$ concentration (6.4 mg N-NO ${ }_{x} /(\mathrm{L} \cdot \mathrm{h})$ ) were lowest (Fig. 4). Because the rate of the increase in $\mathrm{N}-\mathrm{NO}_{x}$ concentration in reactors with carriers was lower than in the control reactor, this means that during aeration phase the $\mathrm{N}^{-\mathrm{NO}_{x}}$ produced in ammonium oxidation was partially simultaneously reduced. $\mathrm{N}_{\text {red }}$ includes the amount of nitrogen reduced during both the mixing and the aeration phases. The nitrate concentration (nitrate that was left over from the previous cycle) immediately decreased during the mixing phase, and after $1 \mathrm{~h}$ of the phase, it was less than $1 \mathrm{mg} \mathrm{N}-\mathrm{NO}_{3} / \mathrm{L}$, which could indicate that nitrogen removal with the use of organic compounds under anoxic conditions is linked to heterotrophic denitrification (Schmidt et al. 2003). This connection is also suggested by the fact that, in the mixing phase, organics were available for microorganisms.

The decrease in $\mathrm{N}-\mathrm{NO}_{x}$ concentrations during mixing phase proceeded according to 1 st-order model. In $R_{0}, R_{\mathrm{FC}}$ and $R_{\mathrm{SC}}$, the rate of ${\mathrm{N}-\mathrm{NO}_{x}}_{x}$ decrease $\left(r_{\mathrm{N}-\mathrm{NO} x(\mathrm{M})}\right)$ was $62.9,83.5$ and $34.2 \mathrm{mg} \mathrm{N}-\mathrm{NO}_{X} /(\mathrm{L} \cdot \mathrm{h})$, respectively (Fig. 5). The presence of carriers and their type determined in which phase of the cycle denitrification occurred. The nitrate concentration reduced in the mixing phase constituted ca. $63 \%, 42 \%$ and $26 \%$ of $\mathrm{N}_{\text {red }}$ during the cycle in $R_{0}, R_{\mathrm{FC}}$ and $R_{\mathrm{SC}}$, respectively.
It should be emphasized that, in $R_{0}$, the amount of $\mathrm{N}_{\text {red }}$ in aeration phase was lower (ca. 35\%) than the amount in the reactors with carriers (to 75\%). Denitrification in aeration phase was favored by the presence of the carriers and oxygen depletion phase (Fig. 4).

In the present study in all reactors, COD removal proceeded with 0 -order model in mixing phase and with pseudo-1st-order model in aeration phase (Fig. 5).

The rate of COD removal was much lower in the mixing phase $\left(r_{\mathrm{COD}(\mathrm{M})}\right)$ than in the aeration phase $\left(r_{\mathrm{COD}(\mathrm{A})}\right)$. In $R_{0}$, $R_{\mathrm{FC}}$ and $R_{\mathrm{SC}}, r_{\mathrm{COD}(\mathrm{M})}$ was $17.2,50.4$ and $27.9 \mathrm{mg} \mathrm{COD}(/ \mathrm{L} \cdot \mathrm{h})$, respectively. After the mixing phase, the concentrations of COD had been reduced by 115,194 and $139 \mathrm{mg}$ COD/L, respectively. The amount of organics per gram of nitrogen removed in the mixing phase (the $\mathrm{COD} / \mathrm{N}-\mathrm{NO}_{3}$ ratio) was determined. This was based on the assumption that organic compounds were only used for nitrate removal in denitrification. This ratio was lower in $R_{0}\left(5 \mathrm{mg} \mathrm{COD} / \mathrm{mg} \mathrm{N}-\mathrm{NO}_{3}\right)$ than in two reactors with carriers (ca. $11.5 \mathrm{mg} \mathrm{COD} / \mathrm{mg} \mathrm{N}-\mathrm{NO}_{3}$ ). If biomass synthesis was taken into account, these ratios would be slightly lower. The rate of COD removal in the aeration phase was lowest in $R_{0}, 567.4 \mathrm{mg} \mathrm{COD} /(\mathrm{L} \cdot \mathrm{h})$, and 1.07 and 1.37-times higher in $R_{\mathrm{FC}}$ and $R_{\mathrm{SC}}$, respectively.

Despite the fact that, in all reactors, the $\mathrm{N}^{*}$ concentrations were similar (Fig. 4), the presence of carriers stimulated nitrogen removal. As a result, the final content of oxidized nitrogen forms was lower in the reactors with immobilized biomass. Nitrogen removal could have been stimulated by diffusion limitation in the biofilms on the carriers, which created DO gradients. In the aerobic layers of the biofilms, nitrification would take place, whereas in the deeper, anoxic layers, denitrification would be favored. In this process of SND taking place in one reactor, less oxygen is required for nitrification, and less organic carbon is needed for denitrification (Münch et al. 1996). Bernat et al. (2013) found that the effectiveness of nitrogen removal via SND was ca. 50\% during the treatment of reject water with a low $\mathrm{COD} / \mathrm{N}$ ratio in an SBR with a modified working cycle. For this kind of wastewater, nitrogen removal via SND in a one-stage SBR is especially advantageous compared to sequential nitrification and denitrification. Koc-Jurczyk and Jurczyk (2017) also found that SND took place in reactors with immobilized biomass, as shown by $\mathrm{N}-\mathrm{NH}_{4}$ removal without the presence of $\mathrm{N}-\mathrm{NO}_{2}$ and $\mathrm{N}-\mathrm{NO}_{3}$ in the effluents; however, it was 
$\mathbf{R}_{0}$

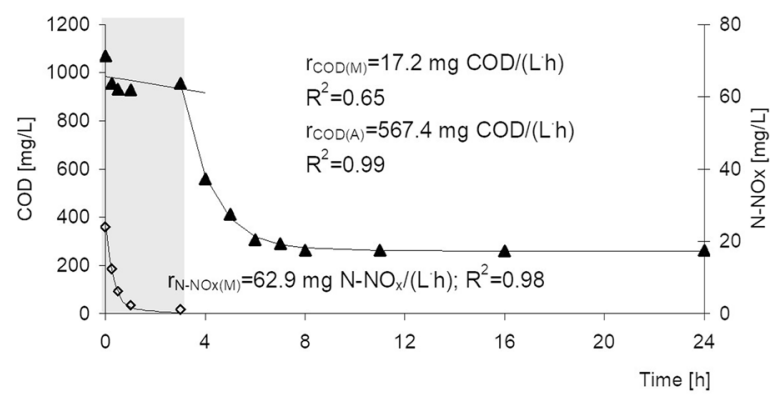

$\mathbf{R}_{\mathrm{FC}}$

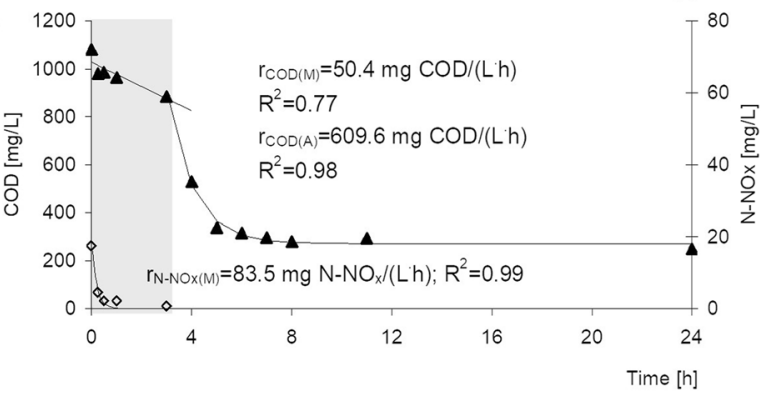

$\mathbf{R}_{\mathrm{SC}}$

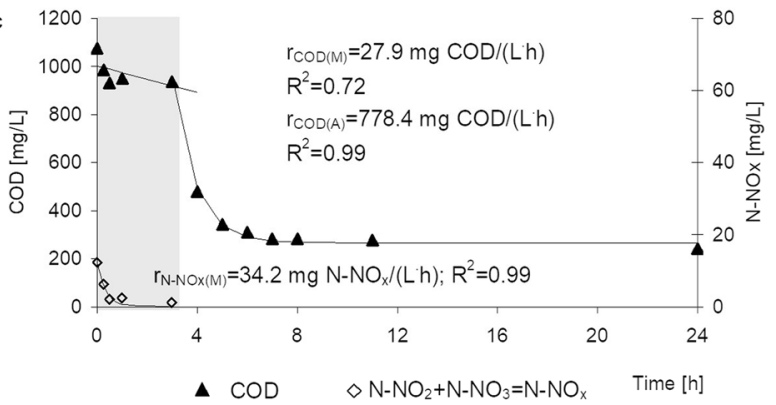

Fig. 5 Changes in the concentrations of COD during the reactors cycle and in the concentrations of oxidized forms of nitrogen during mixing phase of the cycle at $v_{\mathrm{er}} 0.5 \mathrm{~d}^{-1}$; the rates of COD removal during mixing phase $\left(r_{\mathrm{COD}(\mathrm{M})}\right)$ and during aeration phase $\left(r_{\mathrm{COD}(\mathrm{A})}\right)$, and the rate of the decrease in oxidized nitrogen forms $\left(r_{\mathrm{N}-\mathrm{NO} x(\mathrm{M})}\right)$ during mixing phase are given

observed during the treatment of old landfill leachate in which biodegradable organics are present in small concentrations.

\section{Conclusion}

The present study investigated the application of carriers in SBR-type reactors to improve nitrogen removal from leachate due to simultaneous denitrification that may take place also during aeration phase in the anoxic zones of biomass. The highest effectiveness of nitrogen removal, ca. $73 \%$, was achieved in the SBBR with submerged carriers, in which the total nitrogen content (as a sum of TKN, nitrite and nitrate) in the effluent did not exceed $35 \mathrm{mg} / \mathrm{L}$. Regardless of the reactor type used, the effectiveness of COD removal was $86 \%$, and the contents of organics were too high to discharge the effluent to the environment, according to Polish law. Thus, it would be necessary to apply a second step of treatment, e.g., membrane filtration, to reduce the concentration of organics that are hard-to-degrade.

Acknowledgments The research was funded by the National Science Centre, Poland (Grant No. 2016/21/B/NZ9/03625). Part of this work (COD analysis) was financed by Project financially supported by Minister of Science and Higher Education in the range of the program entitled "Regional Initiative of Excellence" for the years 2019-2022, Grant No. 010/RID/2018/19, amount of funding 12.000.000 PLN.

Ethical approval This article does not contain any studies with human participants or animals performed by any of the authors.

Open Access This article is licensed under a Creative Commons Attribution 4.0 International License, which permits use, sharing, adaptation, distribution and reproduction in any medium or format, as long as you give appropriate credit to the original author(s) and the source, provide a link to the Creative Commons licence, and indicate if changes were made. The images or other third party material in this article are included in the article's Creative Commons licence, unless indicated otherwise in a credit line to the material. If material is not included in the article's Creative Commons licence and your intended use is not permitted by statutory regulation or exceeds the permitted use, you will need to obtain permission directly from the copyright holder. To view a copy of this licence, visit http://creativecommons.org/licenses/by/4.0/. 


\section{References}

Akın BS, Ugurlu A (2005) Monitoring and control of biological nutrient removal in a sequencing batch reactor. Process Biochem 40:2873-2878. https://doi.org/10.1016/j.procbio.2005.01.001

Amin MM, Moazzam MMA (2014) Advanced oxidation treatment of composting leachate of municipal solid waste by ozonehydrogen peroxide. Int J Environ Health Eng 3:21. https://doi. org/10.4103/2277-9183.138415

APHA (1992) Standard methods for the examination of water and wastewater, 18th edn. APHA, Washington, DC

Arp DJ, Bottomley PJ (2006) Nitrifiers: more than 100 years from isolation to genome sequences. Microbe 1:229-234

Artiga P, Oyanedel V, Garrido JM, Mendez R (2005) An innovative biofilm-suspended biomass hybrid membrane bioreactor for wastewater treatment. Desalination 179:171-179. https://doi. org/10.1016/j.desal.2004.11.065

Bernat K, Kulikowska D, Zielińska M, Cydzik-Kwiatkowska A, Wojnowska-Baryła I (2013) Simultaneous nitrification and denitrification in an SBR with a modified cycle during reject water treatment. Arch Environ Prot 39:83-91. https://doi.org/10.2478/aep-2013-0008

Bohdziewicz J, Bodzek M, Gorska J (2001) Application of pressure driven membrane techniques to biological treatment of landfill leachate. Process Biochem 36:641-646. https://doi.org/10.1016/ S0032-9592(00)00259-4

Çakmakcı M, Özyaka VŞ (2013) Aerobic composting leachate treatment by the combination of membrane processes. Waste Manag Res 31:187-193. https://doi.org/10.1177/0734242X12462283

Carrera J, Baeza JA, Vicent T, Lafuente J (2003) Biological nitrogen removal of high-strength ammonium industrial wastewater with two-sludge system. Water Res 37:4211-4221. https://doi. org/10.1016/S0043-1354(03)00338-5

Chatterjee N, Flury M, Hinman C, Cogger CG (2013) Chemical and physical characteristics of compost leachates. A review report prepared for the Washington State Department of Transportation. Washington State University

Christensen JB, Jensen DL, Grøn C, Filip Z, Christensen TH (1998) Characterization of the dissolved organic carbon in landfill leachate-polluted groundwater. Water Res 32:125-135. https://doi. org/10.1016/S0043-1354(97)00202-9

Coelho MAZ, Russo C, Araujo OQF (2000) Optimization of a sequencing batch reactor for biological nitrogen removal. Water Res 34:2809-2817. https://doi.org/10.1016/S0043-1354(00)00010-5

Coskuner G, Curtis TP (2002) In situ characterization of nitrifiers in an activated sludge plant: detection of Nitrobacter spp. J Appl Microbiol 93:431-437. https://doi.org/10.1046/j.1365-2672.2002.01715.x

Daniel LMC, Pozzi E, Foresti E, Chinalia FA (2009) Removal of ammonium via simultaneous nitrification-denitrification nitriteshortcut in a single packed-bed batch reactor. Bioresour Technol 100:1100-1107. https://doi.org/10.1016/j.biortech.2008.08.003

Dong W, Lu G, Yan L, Zhang Z, Zhang Y (2016) Characteristics of pellets with immobilized activated sludge and its performance in increasing nitrification in sequencing batch reactors at low temperatures. Int $\mathbf{J}$ Environ Sci 42:202-209. https://doi.org/10.1016/j.jes.2015.09.002

Dosta J, Galí A, El-Hadj TB, Macé S, Mata-Alvarez J (2007) Operation and model description of a sequencing batch reactor treating reject water for biological nitrogen removal via nitrite.
Bioresour Technol 98:2065-2075. https://doi.org/10.1016/j.biort ech.2006.04.033

Fernández-Nava Y, Marañón E, Soons J, Castrillón L (2010) Denitrification of high nitrate concentration wastewater using alternative carbon sources. J Hazard Mater 173:682-688. https://doi. org/10.1016/j.jhazmat.2009.08.140

Foo KY, Hameed BH (2009) An overview of landfill leachate treatment via activated carbon adsorption process. J Hazard Mater 171:54-60. https://doi.org/10.1016/j.jhazmat.2009.06.038

Fromme H, Küchler T, Otto T, Pilz K, Müller J, Wenzel A (2002) Occurrence of phthalates and bisphenol $\mathrm{A}$ and $\mathrm{F}$ in the environment. Water Res 36:1429-1438. https://doi.org/10.1016/S0043 -1354(01)00367-0

García-López J, Rad C, Navarro M (2014) Strategies of management for the whole treatment of leachates generated in a landfill and in a composting plant. J Environ Sci Health, Part A 49:1520-1530. https://doi.org/10.1080/10934529.2014.938526

Hashemi H, Khodabakhshi A (2016) Complete treatment of compost leachate using integrated biological and membrane filtration processes. Iran J Chem Eng 35:81-87

Hashemi H, Ebrahimi A, Khodabakhshi A (2015) Investigation of anaerobic biodegradability of real compost leachate emphasis on biogas harvesting. Int J Environ Sci Technol 12:2841-2846. https ://doi.org/10.1007/s13762-015-0820-3

Hashemi H, Ebrahimi A, Mokhtari M, Jasemizad T (2016) Removal of PAHs and heavy metals in composting leachate using the anaerobic migrating blanket reactor (AMBR) process. Desalin Water Treat 57:24960-24969. https://doi.org/10.1080/19443994.2016.1144529

He XS, Xi BD, Zhang ZY, Gao RT, Tan WB, Cui DY, Yuan Y (2015) Composition, removal, redox, and metal complexation properties of dissolved organic nitrogen in composting leachates. J Hazard Mater 283:227-233. https://doi.org/10.1016/j.jhazmat.2014.09.027

Henze M, Mladenovski C (1991) Hydrolysis of particulate substrate by activated sludge under aerobic, anoxic and anaerobic conditions. Water Res 25:61-64. https://doi.org/10.1016/0043-1354(91)90099-C

Koc-Jurczyk J, Jurczyk L (2017) Biological treatment of landfill leachate at elevated temperature in the presence of polyurethane foam of various porosity. CLEAN Soil Air Water 45:1500264. https:// doi.org/10.1002/clen.201500264

Kotlar E, Tartakovsky B, Argaman Y, Sheintuch M (1996) The nature of interaction between immobilized nitrification and denitrification bacteria. J Biotechnol 51:251-258. https://doi.org/10.1016/ S0168-1656(96)01603-3

Krogmann U, Woyczechowski H (2000) Selected characteristics of leachate, condensate and runoff released during composting of biogenic waste. Waste Manage Res 18:235-248. https://doi. org/10.1177/0734242X0001800305

Kulikowska D, Zielińska M, Konopka K (2019) Treatment of stabilized landfill leachate in an integrated adsorption-fine-ultrafiltration system. Int J Environ Sci Technol 16:423-430. https://doi. org/10.1007/s13762-018-1685-Z

Le HT, Jantarat N, Khanitchaidecha W, Ratananikom K, Nakaruk A (2016) Utilization of waste materials for microbial carrier in wastewater treatment. Biomed Res Int. https://doi. org/10.1155/2016/6957358

Le HT, Jantarat N, Khanitchaidecha W, Ratananikom K, Nakaruk A (2018) Performance of nitrogen removal in attached growth 
reactors with different carriers. J Water Reuse Desalin 8:331-339. https://doi.org/10.2166/wrd.2017.182

Li B, Irvin S, Baker K (2007) The variation of nitrifying bacterial population sizes in a sequencing batch reactor (SBR) treating low, mid, high concentrated synthetic wastewater. J Environ Eng Sci 6:651-663. https://doi.org/10.1139/S07-008

Liu Q, Chen W, Zhang X, Yu L, Zhou J, Xu Y, Qian G (2015) Phosphate enhancing fermentative hydrogen production from substrate with municipal solid waste composting leachate as a nutrient. Bioresour Technol 190:431-437. https://doi.org/10.1016/j.biortech.2015.01.139

Mokhtarani N, Bayatfard A, Mokhtarani B (2012) Full scale performance of compost's leachate treatment by biological anaerobic reactors. Waste Manag Res 30:524-529. https://doi. org/10.1177/0734242X11411014

Münch EV, Lant P, Keller J (1996) Simultaneous nitrification and denitrification in bench-scale sequencing batch reactors. Water Res 30:277-284. https://doi.org/10.1016/0043-1354(95)00174-3

Pei H, Yang Z, Nie C, Hou Q, Zhang L, Wang Y, Zhang S (2018) Using a tubular photosynthetic microbial fuel cell to treat anaerobically digested effluent from kitchen waste: mechanisms of organics and ammonium removal. Bioresour Technol 256:11-16. https://doi. org/10.1016/j.biortech.2018.01.144

Pitter P, Chudoba J (1990) Biodegradability of organic substances in the aquatic environment. CRC Press, Boca Raton, Boston

Renou S, Poulain S, Givaudan JG, Moulin P (2009) Amelioration of ultrafiltration process by lime treatment: case of landfill leachate. Desalination 249:72-82. https://doi.org/10.1016/j.desal.2008.09.007

Romero C, Ramos P, Costa C, Márquez MC (2013) Raw and digested municipal waste compost leachate as potential fertilizer: comparison with a commercial fertilizer. J Clean Prod 59:73-78. https:// doi.org/10.1016/j.jclepro.2013.06.044

Roy D, Azaïs A, Benkaraache S, Drogui P, Tyagi RD (2018) Composting leachate: characterization, treatment, and future perspectives. Rev Environ Sci Biotechnol 17:323-349. https://doi.org/10.1007/ s11157-018-9462-5

Schmidt I, Sliekers O, Schmid M, Bock E, Fuerst J, Kuenen JG, Jetten MSM, Strous M (2003) New concepts of microbial treatment processes for the nitrogen removal in wastewater. FEMS Microbiol Rev 27:481-492. https://doi.org/10.1016/S0168-6445(03)00039-1
Siciliano A, Limonti C, Curcio GM, Calabrò V (2019) Biogas generation through anaerobic digestion of compost leachate in semicontinuous completely stirred tank reactors. Processes 7:635. https ://doi.org/10.3390/pr7090635

Sirianuntapiboon S, Jeeyachok N, Larplai R (2005) Sequencing batch reactor biofilm system for treatment of milk industry wastewater. J Environ Manag 76:77-183. https://doi.org/10.1016/j.jenvman.2005.01.018

Stefanakis A, Akratos CS, Tsihrintzis VA (2014) Vertical flow constructed wetlands: eco-engineering systems for wastewater and sludge treatment, 1st edn. Elsevier Science, Amsterdam, pp 57-84

Tas DO, Karahan Ö, I'nsel G, Övez S, Orhon D, Spanjers H (2009) Biodegradability and denitrification potential of settleable chemical oxygen demand in domestic wastewater. Water Environ Res 81:715-727. https://doi.org/10.2175/106143009X425942

Tatsi AA, Zouboulis AI (2002) A field investigation of the quantity and quality of leachate from a municipal solid waste landfill in a Mediterranean climate (Thessaloniki, Greece). Adv Environ Res 6:207-219. https://doi.org/10.1016/S1093-0191(01)00052-1

Torà JA, Baeza JA, Carrera J, Oleszkiewicz JA (2011) Denitritation of a high-strength nitrite wastewater in a sequencing batch reactor using different organic carbon sources. Chem Eng J 172:994-998. https://doi.org/10.1016/j.cej.2011.07.013

Trebouet D, Schlumpf JP, Jaouen P, Quemeneur F (2001) Stabilized landfill leachate treatment by combined physicochemicalnanofiltration processes. Water Res 35:2935-2942. https://doi. org/10.1016/S0043-1354(01)00005-7

Trujillo D, Font X, Sánchez A (2006) Use of Fenton reaction for the treatment of leachate from composting of different wastes. J Hazard Mater 138:201-204. https://doi.org/10.1016/j.jhazmat.2006.05.053

Vymazal J (2007) Removal of nutrients in various types of constructed wetlands. Sci Total Environ 380:48-65. https://doi.org/10.1016/j. scitotenv.2006.09.014

Vymazal J, Greenway M, Tonderski K, Brix H, Mander Ü (2006) Constructed wetlands for wastewater treatment. In: Verhoeven JTA, Beltman B, Bobbink R, Whigham DF (eds) Wetlands and natural resource management, ecological studies, vol 190. Springer, Berlin, pp 69-94

Xiangli Q, Zhenjia Z, Qingxuan C, Yajie C (2008) Nitrification characteristics of PEG immobilized activated sludge at high ammonia 
and COD loading rates. Desalination 222:340-347. https://doi. org/10.1016/j.desal.2007.01.150

Xie B, Gong W, Tian Y, Qu F, Luo Y, Du X, Tang X, Xu D, Lin D, Li G, Liang H (2018) Biodiesel production with the simultaneous removal of nitrogen, phosphorus and COD in microalgalbacterial communities for the treatment of anaerobic digestion effluent in photobioreactors. Chem Eng J 350:1092-1102. https ://doi.org/10.1016/j.cej.2018.06.032
Zhao HW, Mavinic DS, Oldham WK, Koch FA (1999) Controlling factors for simultaneous nitrification and denitrification in a two-stage intermittent aeration process treating domestic sewage. Water Res 33:961-970. https://doi.org/10.1016/S0043 -1354(98)00292-9 